\title{
Comparisons of Faculty and Student Definitions of Entrepreneurship
}

\section{Mr. Philip M. Reeves, The Pennsylvania State University}

Philip Reeves is a graduate student in the Educational Psychology Department at Penn State. He is working with faculty to evaluate a new university-wide entrepreneurship and innovation minor as a graduate assistant for the Leonhard Center for Enhancement of Engineering Education.

\section{Dr. Sarah E Zappe, Pennsylvania State University, University Park}

Dr. Sarah Zappe is Research Associate and Director of Assessment and Instructional Support in the Leonhard Center for the Enhancement of Engineering Education at Penn State. She holds a doctoral degree in educational psychology emphasizing applied measurement and testing. In her position, Sarah is responsible for developing instructional support programs for faculty, providing evaluation support for educational proposals and projects, and working with faculty to publish educational research. Her research interests primarily involve creativity, innovation, and entrepreneurship education.

\section{Prof. Elizabeth C. Kisenwether, Pennsylvania State University, University Park}

Liz holds a B.S.E.E. from Penn State (1979), and M.S.E.E. degrees from Massachusetts Institute of Technology (1981) and The Johns Hopkins University (1988). She worked in the defense industry for 11 years with HRB Systems/Raytheon, and then co-founded a high-tech startup (Paragon Technology). Since joining Penn State in 1999, Liz has taught design courses in a variety of engineering departments. From 2002-2010, Liz was Director of the Engineering Entrepreneurship (E-SHIP) Minor, serving undergraduates from all majors. She was awarded the 2005 Price Foundation Innovative Entrepreneurship Educators Award - Stanford University. In 2006, she was awarded the ASEE Kauffman Outstanding Entrepreneurship Educator Award. Liz is currently co-Director of the Lion Launch Pad, a student-centric on-campus business accelerator program and is also involved in research funded by NSF and NCIIA (National Collegiate Inventors and Innovators Alliance). Between 2008-2012, Liz supported ASME's annual Innovation Showcase (I-SHOW), was a faculty adviser for the Kern Family Foundation's KEEN (Kern Engineering Entrepreneurship Network) program, and served as Division Chair and Program Chair of the ASEE Entrepreneurship Division. In 2013, Penn State's new Intercollege Minor in Entrepreneurship and Innovation (ENTI) was approved, with five focus areas for undergraduate students to select from: Food and Bio-Innovation, New Media, New Ventures, Social Entrepreneurship and Technology Based Entrepreneurship.

\section{Jake Follmer, The Pennsylvania State University}

D. Jake Follmer is a first-year Ph.D. student in educational psychology at The Pennsylvania State University. He received his M.S.Ed. in 2013 from Bucknell University with certification in school psychology. He received his B.A. in psychology in 2010 from Lycoming College. His interests are in the areas of learning, assessment, and cognition. His research interests lie in the areas of self-regulation, metacognition, executive function, and problem solving.

\section{Ms. Jessica Menold}

Jessica Menold is a doctoral student in mechanical engineering at the Pennsylvania State University. As an undergraduate at Penn State she was heavily involved with a STEM outreach program called the engineering ambassadors. She currently works as a graduate mentor for entrepreneurial student groups on campus as a part of Penn State's Lion Launch Pad team. Her interests in entrepreneurs, as well as engineering education, has led her to the study of innovation in engineers, working with Dr. Kathryn Jablokow. Her current research focuses on understanding innovation in engineering professionals and students, and she is collaborating with a team at Purdue to create a tool to measure innovativeness among engineers. 


\title{
Comparisons of Faculty and Student Definitions of Entrepreneurship
}

\begin{abstract}
In this study, two groups of people, instructors who taught entrepreneurial focused classes $(\mathrm{N}=46)$ and students enrolled in entrepreneurial classes $(\mathrm{N}=138)$ were asked to define entrepreneurship. The responses were coded into general categories and the categories were compared across groups. Student responses were also analyzed based on several other demographic variables including gender, relationship to entrepreneurial parents, prior entrepreneurial experiences, and major. Results highlight some of the different perceptions and goals that students and faculty hold regarding entrepreneurship.
\end{abstract}

\section{Introduction}

Many different definitions of entrepreneurship exist in various academic and business disciplines and discourses. In some ways the ambiguity in the definition of entrepreneurship is appropriate, as different markets, contexts, businesses, and ventures spawn unique problems that require creative thinking and the innovative use of skills. One entrepreneur's specific skills and insights may be highly valuable and relevant in one scenario and inappropriate in another.

Teaching students to develop the entrepreneurial mindset can also be challenging since the associated skills are not completely agreed upon in the academic literature. The goal of this study is not to provide a definitive definition of entrepreneurship or a complete list of the entrepreneurial skills that are needed to be successful, but to examine instructors and students' definitions of entrepreneurship in order to explore and evaluate the congruence between instructional goals and student expectations. Additionally, we will examine whether student expectations differ according to academic discipline (i.e. engineering versus business), gender, relationship to entrepreneurs, and entrepreneurial experience.

\section{Defining Entrepreneurship}

A definitive definition of entrepreneurship is elusive and may contribute to the apprehension of students when considering to learn about or engage in entrepreneurial activities. Almost every article that addresses entrepreneurship or entrepreneurial education contains a definition. While many contain similar elements, there are distinct differences, which are illustrated in the following examples. Two examples are discussed here to provide insight into how different entrepreneurial skills, knowledge and aptitudes can be building blocks of the definition of entrepreneurship.

Churchill defined entrepreneurship as the "process of uncovering or developing an opportunity to create value through innovation and seizing that opportunity..." (p . 586) ${ }^{1}$. There are four important elements in this definition. The first element highlights an entrepreneur's ability to uncover an opportunity. Few people would disagree that opportunity recognition is an important skill of an entrepreneur, and this skill is frequently listed as an indicator of entrepreneurial ability or intention ${ }^{2,3}$. However, there is some debate as to whether or not this skill can actually be taught. ${ }^{4}$ 
The second and third elements of Churchill's definition are related and describe the notion that entrepreneurs create value through innovation, which stresses two important skills or characteristics of entrepreneurs: business acumen and creative thinking. Efforts in entrepreneurial education frequently stress the concept of value creation through the instruction and development of business skills, likely because certain types of value can be easily quantified. Furthermore, existing courses at many institutions already teach relevant business skills. Some may even consider business skills as the most important element of the definition because without teaching individuals how to bring ideas to the market, it would be nearly impossible to turn their ideas into commercial products, services or ventures.

Innovative ability is much more difficult to quantify, but generally involves creating, modifying, or improving a product, service, or process ${ }^{5}$. Innovativeness likely draws from an individual's creativity and ability to identify a need or recognize an opportunity ${ }^{6}$. Similar to the debate surrounding opportunity recognition there is discussion as to whether or not this skill can actually be taught ${ }^{7,8}$.

Finally, the fourth element of Churchill's definition indicates that entrepreneurs seize opportunities. This element may be the most difficult to categorize because it could contain any number of skills including networking ability, teamwork, or motivation to name a few. Successful entrepreneurs take action to move valuable product or service ideas ahead. Subsequently, diligent persistence and passion are desired traits in entrepreneurs, which are frequently measured on entrepreneurial assessments ${ }^{9}$.

Churchill's definition highlights what many people would consider important skills and traits of entrepreneurs. Many other definitions exist in the literature including the definition championed in Kriewall when presenting the KEEN (Kern Entrepreneurship Education Network) program's effort at increasing the entrepreneurial mindset in engineers. This definition, coined by John Hughes, states that entrepreneurship is "self-employment through business ownership that has significant elements of risk, control, and reward ${ }^{9}$."

Clearly, Kriewall's definition views entrepreneurship from a different perspective: essentially, entrepreneurship involves business ownership. The other elements illustrate that entrepreneurs need to be comfortable with all of the aspects associated with being the person in charge. Risk tolerance is frequently mentioned as an entrepreneurial trait ${ }^{9,10}$, as is the notion that entrepreneurs tend to enjoy determining their own career path ${ }^{11}$. In essence, the success or failure of the business and the entrepreneur rests on their ability to navigate their chosen marketplace. Undoubtedly, many individuals view entrepreneurship in a similar manner, which may seem extremely appealing or terrifying depending on their tolerance for risk, ability to learn from failure, and capacity for leadership.

Kriewell's definition is more concise and somewhat more narrowly focused than Churchill's definition. That is not to say that one is superior to the other. In fact, these two definitions were chosen simply to illustrate the differences that exist between various conceptualizations of entrepreneurship within the academic literature. Additional reviews and discussions of definitions of entrepreneurship in general ${ }^{12}$, specific types of entrepreneurship ${ }^{13}$, and intrapreneurship ${ }^{14}$ are available in the literature, but go beyond the scope of this paper. 
In this study, we will not be advocating for one definition over another. Instead, the purpose of this study is to examine how students who are just beginning their coursework in an entrepreneurial minor define entrepreneurship. The students' responses will then be compared to a group of faculty members that teach entrepreneurial related classes and in many cases have entrepreneurial experiences who were also asked to provide a definition. Responses will be compared in an attempt to understand students' baseline understanding of entrepreneurship and gain insight into why students decide to pursue entrepreneurial activities.

\section{Procedure}

Recently, students at Penn State began enrolling in the new university-wide Entrepreneurship and Innovation Minor. The minor, which had been previously housed in the College of Engineering, had transitioned to a university-wide minor in the fall of 2013. As a part of the evaluation plan of the newly defined minor, all students enrolled in the core courses were asked to complete a survey. The survey included an open-ended prompt which asked students to define entrepreneurship. The survey was distributed during the first two weeks of the semester to ensure that the students' responses would not be influenced by the course content. The survey was administered online using Qualtrics, a commercially available software tool.

Data was also collected from instructors through the use of an online survey. The data was collected as part of a larger study on faculty beliefs of entrepreneurship education, which is detailed in another publication ${ }^{15}$. Although the survey included a variety of questions asking about faculty beliefs of entrepreneurship education, the responses to the definition question ("In your own words, without referencing any online material, define entrepreneurship.") will be presented in this paper.

\section{Participants}

Student participants were recruited from six separate entrepreneurial-focused courses at a large mid-Atlantic research-focused university. The completion rate of the survey was $82.63 \%$ (138 out of 167), and 125 of the students were taking their first entrepreneurship-related class. Some students did, however, have previous exposure to entrepreneurs with 99 students reporting that they were closely related to an entrepreneur or small business owner, and 35 students reporting that they were currently working on developing a new product or venture.

Students participated from nine different colleges. The majority of students were from Engineering $(\mathrm{N}=31)$, Business $(\mathrm{N}=36)$, Communication $(\mathrm{N}=15)$, and Hotel and Restaurant Management $(\mathrm{N}=29)$ with 15 students representing the four other colleges. Males were also more heavily represented $(\mathrm{N}=94)$ than females $(\mathrm{N}=38)$.

The instructors ( $\mathrm{N}=46)$ who participated in the study were identified as having taught entrepreneurship specifically to engineering students. As mentioned above, the data from the instructors was from a larger study examining faculty beliefs. The methodology for the collection of the instructor data is detailed in Besterfield, Shartrand and Zappe ${ }^{16}$. Two recruitment methods were used to identify instructors. First, directors of programs that taught entrepreneurship to engineering students were identified and asked to recruit at least one faculty

member who was teaching entrepreneurship. Secondly, e-mail invitations were sent to faculty 
on list-serves available from the National Collegiate Inventors and Innovators Alliance (NCIIA). Using both of these methods, a total of 46 instructors participated and provided responses to the questions analyzed in this paper.

\section{Analysis}

The responses from the students and instructors were first analyzed using open coding. Individual elements of each definition were isolated. For example, one student's definition was "It means to take a risk and to start a business." The elements of this definition were "to take a risk" and "to start a business." From these elements, axial coding techniques were used to identify general themes. As a result, an individual definition might be classified into several themes.

After examining all of the initial themes, the responses were examined again for congruence, which resulted in a final total of sixteen themes. The themes were then grouped into three more general categories. The faculty and student responses were then compared (Table 1), and the student responses were examined further based upon student gender (Table 2), prior exposure to (Table 3), experience with entrepreneurship (Tables 4), and college affiliation (Table 5).

\section{Results}

\section{Categories and Themes}

Three general categories emerged from the data: creation and development, entrepreneurial skills and characteristics, and goals and outcomes of entrepreneurship. Within each category, a number of more specific themes emerged, which will be elaborated in the following paragraphs and are listed in all of the Tables (i.e. Tables 1-5).

\section{Category 1: Creation and Development}

Participants who included elements of creation and development in their definition indicated that entrepreneurship was focused on starting a new endeavor. The themes that emerged in this general category focused on starting a business, creating and developing a product, creating or providing a service, or working on and developing a new venture. Example definitions in this category include: "entrepreneurship is starting and developing your own business;" "an individual who starts their own business venture, company, innovative product, or service;" and "the activity of transforming ideas into economic "goods", services, products, organizations, etc."

Descriptively, distinct differences emerged between faculty and student responses within this category (Table 1$)$. A statistically significant $\chi^{2}(1, \mathrm{~N}=184)=3.74, p=.034$ relationship was found between the type of participant (students or instructors) and the inclusion of the "starting a business" element in the definition. A larger percentage of students' (41.3\%) definitions contained the element when compared to the instructors' definitions (23.9\%). However, the instructors' definitions included significantly higher rates of the "creating and developing other products" element $(28.3 \%$ vs. $10.9 \%) \chi^{2}(1, \mathrm{~N}=184)=8.09, p=.004$ and the "services" element $(17.4 \%$ vs. $5.1 \%) \chi^{2}(1, \mathrm{~N}=184)=6.99, p=.008$. While the difference in ventures $(13.8 \% \mathrm{vs}$. 
$23.9 \%$ ) is only descriptive, the overall results still illustrate that faculty members likely possess a more diverse and inclusive vision of entrepreneurial endeavors than students.

Interestingly, differences within the student data were also found for this category (Table 2). Males and females included starting a business at similar rates, but males included products and services at a higher rate, while females included ventures at a higher rate. This may partially explain the gender differences in major or college enrollment (engineering vs. hotel and restaurant management). Nevertheless, preconceived notions of entrepreneurship may be somewhat influenced by gender.

Students who reported that they were currently working on a new venture also appeared to differ from their peers who were not currently working on a current venture in this category (Table3). A statistically significant relationship was found between the rates of inclusion of the "starting a business" element and the students' personal entrepreneurial experience $\chi^{2}(1$, $\mathrm{N}=132)=8.05, p=.005$, with only $20.0 \%$ of students who were working on a new venture including it compared to $47.4 \%$ from students who were not working on a new venture. Differences in the inclusion of the other themes (i.e. products, services, and ventures) were minimal. Similarly, only small differences existed on all of the themes between students who had or did not have entrepreneurs as relatives. Consequently, exposure to entrepreneurs or entrepreneurial activities did not seem to have a large impact on perceptions and definitions in this category.

While the small sample sizes of students from each college make it difficult to produce meaningful statistical evidence, the descriptive results still provide useful insight. Students from all majors perceived entrepreneurship to involve more business creation than the development of other product, services, or ventures. The only other large percentages came from business students who included other ventures at a relatively high rate $(27.8 \%)$ and communication students who included product development at a relatively high rate $(20.0 \%)$.

\section{Category 2: Entrepreneurial Skills and Characteristics}

The themes included in this category represent the many roles, abilities, skills, and personal characteristics that the participants reported in their definitions of entrepreneurship. Many of the elements included in these themes operationalize entrepreneurship. While the nature of some of the themes may potentially overlap, distinctions were clearly articulated within the participants' definitions.

The eight themes in this group are: creativity and innovation in problem solving, finding solutions, creating something new, or adapting existing work; the ability to recognize opportunities and potential; the ability to generate and develop ideas; the knowledge and ability to bring an idea to market; possessing the drive, motivation, and the willingness to take action; the ability to handle, mitigate, or accept risk in business or investing; the knowledge or ability to find, manage, and utilize resources; and other assorted skills that occurred at least once in the definitions. In the following paragraphs, examples of definitions containing elements from each theme will be provided, along with the results from the comparisons of gender, relationship to entrepreneurs, entrepreneurial experience, and college enrollment. 


\section{Creativity and Innovation}

Elements in this theme point to the role that creativity and innovation play in problem solving, finding solutions, creating something new or adapting existing work. Example definitions for this theme include: "creating and improving a product or service to better fit the needs of an individual"; "the ability to make something out of nothing and sell it as a life changing product"; "entrepreneurs play the role of change agents in their sector"; and "entrepreneurship is the combination or recombination of resources in innovative and valuable ways."

Students and instructors included this characteristic at significantly different rates $(25.4 \%$ and $41.3 \%$ respectively) $\chi^{2}(1, \mathrm{~N}=184)=4.23, p=.04$, indicating that instructors may view creativity and innovation to be more crucial to the entrepreneurial process. Additionally, students' previous entrepreneurial experience did result in significantly different rates of inclusion. Students who reported that they were currently working on a new venture included creativity or innovation in $45.7 \%$ of definitions compared to $17.5 \%$ from students not working on a current venture $\chi^{2}(1, \mathrm{~N}=132)=10.9, p=.001$.

Interestingly, students with entrepreneurial relatives included this characteristic more (28.9\%) than students without entrepreneurial relatives $(13.9 \%)$ though this fell short of statistical significance. Male and female students included this characteristic at similar rates (26.6\% and $21.1 \%$ respectively). Business students included this characteristic $(44.4 \%)$ much more often in their definition than communication students $(26.7 \%)$, engineering students $(16.2 \%)$, and hotel and restaurant management students $(10.3 \%)$.

\section{Opportunity Recognition}

Elements in this theme point to an entrepreneur's ability to recognize opportunities and potential. Example definitions for this theme include: "creating, seeing, and acting on business opportunities"; "entrepreneurs are the constant observers of the human condition in which they find opportunities for improving the world through profitable ventures"; "entrepreneurship is the art of innovation and improvement of the world"; and "entrepreneurship is finding opportunities in a market or with a product and bringing them to life through business."

Students and instructors included this characteristic at significantly different rates $(8.0 \%$ and $23.9 \%$ respectively) $\chi^{2}(1, \mathrm{~N}=184)=8.33, p=.004$, highlighting the importance that instructors place on being able to recognize opportunities. However, student gender, entrepreneurial experience, and relationships with entrepreneurs did not seem to influence the rate of inclusion of this characteristic. Additionally, students from the four represented colleges included opportunity recognition at similar rates.

\section{Idea Generation and Development}

Elements in this theme point to an entrepreneur's ability to generate and develop ideas. Example definitions for this theme include: "entrepreneurship is when an idea that creates something new or improves a problem is pursued"; "is the step an individual takes to create self worth through developing or perfecting an idea"; "entrepreneurship is developing one's own business idea"; and "using personal vision and drive to convert an idea to reality." 
Students and instructors included this characteristic at similar rates $(22.5 \%$ and $19.6 \%$ respectively). Female students included the characteristic at a higher rate than males $(31.6 \%$ and $20.2 \%$ ), but the difference did not reach statistical significance. Similarly, no significant relationships were found based on entrepreneurial experience or having an entrepreneurial relative. Students enrolled in hotel and restaurant management programs $(31.1 \%)$ and engineering programs $(27.0 \%)$ rated this characteristic higher than business $(19.4 \%)$ and communication (13.3\%) students. Regardless of the demographic variables, it seems that idea generation and development is a commonly perceived characteristic.

\section{Bringing an Idea to Market}

Elements in this theme point to an entrepreneur's knowledge and ability to bring an idea to market. Example definitions for this theme include: "the act of taking an idea and using it in a new way to make a profit by providing it to a market, new or existing;" "entrepreneurship is when a person develops a business idea and takes it to market," and, "it involves matching business ideas to market opportunities."

Students and instructors included this characteristic at similar rates $(26.1 \%$ and $19.6 \%$ respectively. Female students included the characteristic at a higher rate than males $(34.2 \%$ and $22.3 \%$ respectively), but the difference did not reach statistical significance. Similarly, no significant relationships were found based on prior exposure or having an entrepreneurial relative. Students enrolled in hotel and restaurant management (34.5\%) and communication programs $(33.3 \%)$ rated this characteristic higher than business (13.9\%) and engineering $(24.3 \%)$ students. Regardless of the demographic variables, it seems that an individual's ability to bring an idea to market is an important characteristic of an entrepreneur.

\section{Drive, Motivation, Taking Action}

Elements in this theme point to the notion that entrepreneurs are driven and motivated individuals with a willingness to take action. Example definitions for this theme include: "the drive to follow a passion and to invest yourself in a business you choose"; "it is the drive of coming up with ideas and processing those ideas until it becomes a successful business venture"; and "the principles of a risk-taking, caring, and dedicated individual who looks for problems in people's lives consciously in order to see them as opportunities."

Students and instructors included this characteristic at different rates $(26.8 \%$ and $41.3 \%$ respectively). However, the relationship did not rise to the level of statistical significance $\chi^{2}(1$, $\mathrm{N}=184)=3.42, p=.064$. Similarly, no significant relationship was found based on gender, prior exposure, or having an entrepreneurial relative. Descriptively, $42.9 \%$ of students working on a current venture included this theme, while only $21.6 \%$ of students not working on a current venture included this theme. Business students included this theme at the highest rate $(38.9 \%)$, followed by communication students (33.3\%), engineering students $(21.6 \%)$, and hotel management students (10.3\%).

\section{Taking a Risk}

Elements in this theme point to an entrepreneur's ability to handle, mitigate, or accept risk in business or investing. Example definitions for this theme include: "someone who pursues 
an idea and is willing to take risks for that idea"; "business person willing to bet that their idea will survive the odds of failure no matter what"; and "entrepreneurship is the nature of being an entrepreneur who is capable to invent an innovative product or a business and takes the risk by going one step further to make it successful."

There was not a significant relationship between participant type and inclusion of elements in this theme. There were also no significant differences between inclusion rates in students based on gender, parental relationship, or current entrepreneurial ventures. The largest descriptive difference was between students currently working on a new venture $(11.4 \%)$ and students not currently working on a new venture $(22.7 \%)$. Business students included this theme at the highest rate $(27.8 \%)$, followed by engineering students $(21.6 \%)$, communication students $(20.0 \%)$, and hotel management students $(17.2 \%)$.

\section{Resource Management}

Elements in this theme point to an entrepreneur's knowledge or ability to find, manage, and utilize resources. Example definitions for this theme include: "entrepreneurship, the study of innovative thinking and being able to recognize and utilize the resources available in order to capitalize on them" and "entrepreneurship is being able to come up with innovative ideas and use all available resources to further your ideas and being able to market them."

Students and instructors differed significantly on the inclusion of this theme $(2.2 \%$ and $13.0 \%$ respectively) $\chi^{2}(1, \mathrm{~N}=184)=8.76, p=.003$. There were no significant differences between students based on gender, parental relationship, or current entrepreneurial ventures. Interestingly, only business $(5.6 \%)$ and engineering students $(2.7 \%)$ included resource management elements in their definitions.

\section{Other skills}

Other assorted skills and traits that occurred at least once in the definitions such as leadership, communication ability, organization, management ability, marketing ability teamwork, and competitiveness were included in this theme. Example definitions include: "Entrepreneurs are the constant observers of the human condition in which they find opportunities for improving the world through profitable ventures"; "It is the will to develop and manage a business firm. The good entrepreneurs are the one who have leadership quality"; and "all the qualities of an entrepreneur put into effect, such as leadership, social interaction, moderate risk taking." There was no real difference in inclusion rates between students and faculty or within students based on the other demographic variables.

\section{Category 3: Goals and Outcomes}

The themes included in this category centered around the personal reasons for pursuing entrepreneurial activities and the anticipated outcomes that participants included in their definitions. The themes that were identified include: the feelings and desire for financial and intellectual independence, the pursuit or generation of profit, the creation of value, and a listing of other outcomes. In the following paragraphs, examples of definitions containing each remaining theme will be provided, along with the results from the comparisons of gender, prior exposure to entrepreneurship, and college enrollment. 


\section{Financial and Intellectual Independence}

Elements in this theme point to the participant's desire to work and provide for themselves while following their own dreams and goals. Example definitions with elements in this theme include: "working 16 hours a day so you don't have to work 8 a day for someone else"; "this is the characteristic of someone willing to set out on their own venture and take their own educated risks in the effort to succeed"; "pursuing your own goals and aiming towards success"; and "entrepreneurship simply means being your own boss. It involves the ability to run a business (regardless of the size) on your own."

Students and instructors differed on the rate of inclusion of this theme $(26.8 \%$ and $8.7 \%$ respectively) $\chi^{2}(1, \mathrm{~N}=184)=6.54, p=.013$. No other statistically significant relationships were found, but males (31.9\%) included this theme at a higher rate than females (15.8\%). Engineering students included this theme at the lowest rate $(21.6 \%)$ while the inclusion rates from other colleges all ranged between $27.6 \%$ and $33.3 \%$.

\section{The Pursuit and Generation of Profits}

The elements that were combined to create this theme focused on creating or generating profit or money. Example definitions with elements included in this theme include: "entrepreneurship is being involved in owning and creating a business. It means risking capital in order to achieve profit and growth in the long term"; "starting businesses; finding ways to solve problems and profit from it"; "the study or practice of building and maintaining a profitable business"; and "entrepreneurship is taking your ideas and developing a business plan that creates a need and want for a particular target market for a profit."

No differences were found on the rate of inclusion of this theme between students and instructors or within students based on gender, familial relationship, or current project status. Interestingly, business students included this theme at the lowest rate $(2.8 \%)$ when compared to communication students $(20.0 \%)$, engineering students $(21.6 \%)$, and hotel management students $(27.6 \%)$.

\section{Value Creation}

The elements that were combined to create this theme focused on the creation of value, which did not specifically pertain to profits or money. Example definitions with elements classified in this theme include: "entrepreneurship is a person that takes an idea or concept and either creates their idea for beneficial reasons or presents their idea to someone who can create it"; "the identification of a problem followed by a commitment to solve it through the creation of an innovative product or process that creates value"; "the ability to create, market and deliver real value with limited resources"; and "pursuing a venture while taking on due risk to try to create value."

Students and instructors did not significantly differ in their rates of inclusion $(3.6 \%$ and $17.4 \%$ respectively) $\chi^{2}(1, \mathrm{~N}=184)=2.60, p=.107$. None of the other demographic variables produced very large differences on this theme. Additionally, the differences across majors in this theme were not particularly large. 


\section{Other Outcomes}

Some of the other outcomes that were listed in small numbers included increased feelings of self-worth, becoming self-actualized, an accumulation of power and network contacts, and the generation of sustainable solutions. Example definitions include: "Entrepreneurship is the competitive search for opportunities that will increase your wealth, power, or network abilities"; "Entrepreneurship is the urge to accomplish a greater goal by completing routine tasks in order to get there"; "Is the step an individual takes to create self worth through developing or perfecting an idea"; and "Entrepreneurship is the innovation of a person in creating a better world for others to live that no one has done before."

Instructors were more likely to include indicators of other outcomes in their definitions than students $\left(28.3 \%\right.$ and $9.4 \%$ respectively) $\chi^{2}(1, \mathrm{~N}=184)=10.10, p=.001$. The other demographic variables did not indicate any relationships in the rates of the inclusion of other outcomes in student definitions.

\section{Discussion}

Several aspects of the instructors' and students' definitions clearly differed. The statistically significant differences found between the students' and instructors' rates of inclusion of the elements within each theme are listed here.

- Students included higher rates of financial and intellectual independence than instructors.

- Students included starting a business at a higher rate than instructors.

- Instructors included creating and developing a service at a higher rate than students.

- Instructors included creating and developing products at a higher rate than students.

- Instructors included creativity and innovation at a higher rate than students.

- Instructors included opportunity recognition at a higher rate than students.

- Instructors included resource management at a higher rate than students.

- Instructors included indicators of other outcomes at a higher rate than students.

In general, students perceived entrepreneurship as a way to have a career in which they were to be their own boss and start their own business. While this finding may not necessarily be surprising given the high profile nature of some young entrepreneurs, the perception may actually prevent some individuals from considering entrepreneurial related careers. The prevalence of the notion of independence was also apparent in student definitions with the distinct lack of the inclusion of teamwork or collaborative skills in their definitions, which have previously been considered important characteristics of entrepreneurs ${ }^{5,17}$.

Overall, instructors seem to possess a broader definition of entrepreneurship than students, which may be indicative of their experience and exposure to a wider variety of entrepreneurial endeavors. The skills that instructors included may highlight the skills and goals that they are trying to impart to their students. Creativity ${ }^{18}$, opportunity recognition ${ }^{3,4}$, and resource management ${ }^{5,10}$ are all commonly mentioned elements within the academic literature. As such, it is not surprising that these skills were mentioned at relatively high rates by instructors. Additionally, faculty members were often focused on more than simply profit (although it was still prominent). The inclusion of other outcomes such as "improving the 
world," "sustainability", or "recognizing societal needs" were mentioned by instructors at a much higher rate than students, who again seemed more concerned with starting a business, finding financial success, and independence than their instructors.

The recent economic downturn, poor job market, and increases in tuition rates may greatly influence the current goals of students, giving them a different outlook than their instructors (or possibly even previous generations of students) especially in regard to the need to find a new manner of generating income. In addition, to possible generational differences between the two groups of participants, they may also differ in their level of cognitive and career development. Faculty members are certainly at a different stage of their career than students. A majority of faculty members have found career success in some form or another, while most students are still exploring potential career options. Consequently, their views on the world, motivation, and future goals likely reflect their current status. A longitudinal study examining how perceptions of entrepreneurship change based on career status and stages of adult development would be benefit and provide more insight on this issue.

It is clear, however, that students and faculty members possess different conceptualizations of entrepreneurship. Therefore, it is important to continually track students' perceptions in order to ensure that they view their education as relevant to their future careers and other personal goals. In entrepreneurial education, this may involve exposing students earlier to multiple entrepreneurial career paths and gradually expanding their horizons and definitions of entrepreneurship.

When comparing the responses of students based on various demographic criteria, there were only a couple of statistical differences which are listed here.

- Students not working on a new venture included starting a business more than students who were working on a new venture.

- Students working on a new venture included creativity and innovation more than students who were not working on a new venture.

The only significant differences revolved around having actual personal experience working on entrepreneurial ventures. Given that previous research indicated that having an entrepreneurial parent significantly predicted entrepreneurial activities or intentions, it is somewhat surprising that no significant results were found based on this variable ${ }^{10,19}$. As such, this provides additional evidence supporting active learning and the incorporation of entrepreneurial experiences within the classroom ${ }^{20,21}$. Almost certainly, students gain a new perspective after having hands on experience as opposed to simply observing their parents' or relatives' work habits.

Interestingly, there were no significant differences based on gender, which is somewhat unexpected given the gender differences found in some research studies on entrepreneurship ${ }^{22}$. The largest descriptive differences indicate that males were more concerned with financial and intellectual independence and product creation, while females concentrated more on venture creation, idea generation, and the ability to bring an idea to market. However, these results may be influenced by the difference in gender enrollment in various majors with fewer females majoring in engineering, which may be more product-driven than other majors (Table 6). 
Engineering students also included 'other skills' in their definitions at higher rates than students in other majors. Engineering students frequently referred specifically to business skills, which may highlight the skills that they believe entrepreneurial minded engineers possess. Overall, the differences between students in different majors was relatively minimal, but there were some other surprising descriptive differences such as the low percentage of business students who included the generation of profits in their definitions, and communication students including product development at the highest rates. However, a larger sample within each major would be needed in order to make more conclusions. In the future as the students learn more about their desired profession and entrepreneurship within that professional context, other differences may arise.

\section{Limitations}

The study contained several limitations. First, male students were over represented in the survey. As a result, the overall student responses may reflect some gender bias. Furthermore, while the analysis of student responses by gender did not yield significant results, there were some descriptive differences that may have had a larger impact if more female students were included. Similarly, the gender differences within major may have influenced the results (Table 6 ), as males were more prominently represented in engineering and business programs.

The recruitment of the instructors was another limitation of the study. As mentioned previously, only instructors who taught entrepreneurship to engineering students were surveyed which could have skewed their responses. Even though the instructors come from a variety of backgrounds (i.e. engineering, business, information technology), they were all identified as faculty members who taught entrepreneurship to engineering students (although it is possible that students from other majors were enrolled in their classes). Therefore, their definitions might be slightly more biased in terms of focus on product development and influenced by an engineering viewpoint when compared to students who work and study in other fields such as business or hotel and restaurant management who may focus more on starting or running a small business or service related venture.

Finally, the identification of the elements and themes within the definitions was an interpretive endeavor. While the process was carefully planned and each definition was repeatedly and thoroughly examined and analyzed, it is possible that other researchers may have identified different themes. Consequently, the results of this study should not be generalized beyond this context. Not all students and instructors (even within the sample) define entrepreneurship in the same way. Therefore, this research does not provide or propose a universal definition of entrepreneurship. Instead, the study provides a glimpse into how these students and instructors understand and perceive entrepreneurship at one point in time.

\section{Conclusion}

Many of the themes that were identified by students and instructors in their definitions were consistent with previous conceptualizations of entrepreneurship. Students and instructors clearly differed in regards to certain elements of entrepreneurship, which may be influenced by their varied levels of experiences as well as developmental, generational, and financial differences. As a result, it will be important to continually monitor perceptual differences and 
student expectations in order to combat misconceptions, expand horizons, and provide meaningful entrepreneurial education.

Within student responses, the largest differences occurred between students who were currently working on entrepreneurial ventures, again highlighting the impact that hands-on experience has on knowledge and awareness. Other demographic variables did not produce significant differences at this time, but as students progress through the program, their definitions and perceptions are sure to change. In future studies, it will be interesting to see if student definitions begin to more closely resemble the definitions of their instructors, and if definitions coalesce within the various areas of concentrations as the number of entrepreneurship courses and experiences increase.

\section{References}

1. Churchill, N.C. (1992). Research issues in entrepreneurship. In Sexton, D.L. and Kasarda, J.D. (Eds.), The State of the Art of Entrepreneurship, PWS-KENT, Boston, MA: 570-06.

2. Ozgen, E. \& Baron, R.A. (2007). Social sources of information in opportunity recognition: Effects of mentors, industry networks and professional forums. Journal of Business Venturing, 22(2), 174192.

3. Hills, G.E., Shrader, R.C. \& Lumpkin, G.T. (1999). Opportunity recognition as a creative process. Frontiers of Entrepreneurship Research, 216-227.

4. Ozgen, E. \& Minsky, B.D. (2013). Why some students engage in entrepreneurial activities while others do not. Journal of Entrepreneurship Education, 16, 45-58.

5. Pistrui, D., Bonnstetter, R., Bonnstetter, B. J., \& Fry, C. C. (2012). Creating and assessing a new class of entrepreneurially-minded engineers. Paper presented at the NCIAA Conference, Washington D.C.

6. Kuratko, D. 1995. Entrepreneurship. In International encyclopedia of business and management. London: International Thomson Press.

7. Henry, C., Hill, F., \&: Leitch C. (2005) Entrepreneurship Educational and training: can Entrepreneurship be taught? Part 11 Emerald Group Publishing ltd 47(3), 158 -169.

8. Elmuit, D., Khoury, G., \& Omran, O. (2012). Does entrepreneurship education have a role in developing entrepreneurial skills and ventures' effectiveness. Journal of Entrepreneurship Education, 15, 8397.

9. Kriewall, T. J. (2010). Instilling the entrepreneurial engineering mindset in college undergraduates: A panel presentation. Paper presented at the NCIIA Conference, San Francisco, CA.

10. Duval-Couetil, N., Reed-Rhoads, T., \& Haghighi, S. (2012). Engineering students and entrepreneurship education: Involvement, attitudes, and outcomes. International Journal of Engineering Education, 28, 425-435.

11. Duval-Couetil, N., Reed-Rhoads, T. \& Haghighi, S. (2011). Investigating the impact of entrepreneurship education on engineering students. Paper presented at the NCIAA Conference, Washington D.C.

12. Zimmerman, J. (2008). Refining the Definition of Entrepreneurship. (Doctoral Dissertation). UMI Dissertation Publishing

13. Martin, R.L. \& Osbrg, S. (2007). Social Entrepreneurship: The Case Definition. Palo Alto, CA: Stanford Social Innovation Review.

14. Antoncic, B. \& Hisrich, R. D. (2003). Clarifying the intrapreneurship concept. Journal of Small Business and Enterprise Development, 10, 7-24.

15. Zappe, S. E., Hochstedt, K., Kisenwether, E., \& Shartrand, A. (2013). Teaching to Innovate: Beliefs and perceptions of instructors who teach entrepreneurship to engineering students. International Journal of Engineering Education. 29(1): 45-62.

16. Besterfield, M., Shartrand, A., \& Zappe, S. E. (In press). Faculty and student perceptions of the content of entrepreneurship courses in engineering education. Advances in Engineering Education.

17. Ramirez, C., Hernandez, T., Cardenas, A., Calcedo, L. C., \& Gonzalez, M. A. (2012). Social 
entrepreneurship for engineers. Paper presented at the NCIAA Conference, Washington D.C.

18. Boyles, T. (2012). $21^{\text {st }}$ Century knowledge, skills, and abilities and entrepreneurial competencies: A model for undergraduate entrepreneurship education. Journal of Entrepreneurship Education, 15, 41-55.

19. Bhandari, N.C. (2012). Relationship between students' gender, their own employment, their parents' employment, and the students' intention for entrepreneurship. Journal of Entrepreneurial Education, 15, 133-146.

20. Beaury, R., Boyer, P., \& Kisenwether, E. (2010). Using live cases in problem-based entrepreneurship learning. Paper presented at the NCIAA Conference, San Franscisco, CA.

21. Neumeyer, X. (2013). Examining the role of inquiry-based learning in entrepreneurship education. Paper presented at the NCIAA Conference, Washington D.C.

22. Max, S. \& Ballereau, V. (2013). Theorizing about gender and entrepreneurship: bridging the gap with social psychology. International Journal of Gender and Entrepreneurship, 5, 97-110.

\section{Appendix A: Tables:}

Table 1: Percentage of each category included by students and instructors

\begin{tabular}{lcc}
\hline \multicolumn{1}{c}{ Categories and Themes } & Students & Faculty \\
\hline Creation/Development of a: & & \\
Business & 41.3 & $23.9^{*}$ \\
Product & 10.9 & $28.3^{*}$ \\
Service & 5.1 & $17.4^{*}$ \\
Venture & 13.8 & 23.9 \\
Entrepreneurial Skills & & \\
Creativity and Innovation & 25.4 & $41.3^{*}$ \\
Opportunity Recognition & 8.0 & $23.9^{*}$ \\
Idea Generation and Development & 22.5 & 19.6 \\
Bringing an Idea to Market & 26.1 & 19.6 \\
Drive/Motivation/Taking Action & 26.8 & 41.3 \\
Taking a Risk/Investing & 18.8 & 15.2 \\
Resource Management & 2.2 & $13.0^{*}$ \\
Other Skills/Abilities & 36.2 & 36.2 \\
Goals and Outcomes & & \\
Financial and Intellectual Independence & 26.8 & $8.7^{*}$ \\
Pursuit/Generation of Profit & 15.9 & 13.0 \\
Value Creation & 3.6 & 17.4 \\
Other Outcomes & 9.4 & $28.3^{*}$ \\
\hline
\end{tabular}

*indicates significant difference at $\alpha=.05$

Table 2: Percentage of each category included by male versus female students

\begin{tabular}{ccc}
\hline Category & Male Students & Female Students \\
\hline Creation/Development of a: & & \\
Business & 41.5 & 39.5 \\
Product & 12.8 & 5.3 \\
Service & 7.4 & 0.0
\end{tabular}


Venture

Entrepreneurial Skills

Creativity and Innovation

Opportunity Recognition

Idea Generation and Development

Bringing an Idea to Market

Drive/Motivation/Taking Action

Taking a Risk/Investing

Resource Management

Other Skills/Abilities

Goals and Outcomes

Financial and Intellectual Independence

Pursuit/Generation of Profit

Value Creation

Other Outcomes
10.6

23.7

26.6

21.1

8.5

7.9

20.2

22.3

31.6

28.7

34.2

23.7

20.2

18.4

3.2

39.4

0.0

31.6

31.9

15.8

14.9

18.4

$5.3 \quad 0.0$

7.4

10.5

Table 3: Percentage of each category included by students who are and are not working on a current venture

\begin{tabular}{lcc}
\hline \multicolumn{1}{c}{ Category } & With Current Venture & No Current Venture \\
\hline Creation/Development of a: & & \\
Business & 20.0 & $47.4 *$ \\
Product & 14.3 & 9.3 \\
Service & 8.6 & 4.1 \\
Venture & 14.3 & 14.4 \\
Entrepreneurial Skills/Characteristics & & \\
Creativity and Innovation & 45.7 & $17.5 *$ \\
Opportunity Recognition & 11.4 & 6.2 \\
Idea Generation and Development & 14.3 & 25.8 \\
Bringing an Idea to Market & 28.6 & 25.8 \\
Drive/Motivation/Taking Action & 42.9 & 21.6 \\
Taking a Risk/Investing & 11.4 & 22.7 \\
Resource Management & 5.7 & 1.0 \\
Other Skills/Abilities & 31.4 & 40.2 \\
Goals and Outcomes & & \\
Financial and Intellectual Independence & 20.0 & 29.9 \\
Pursuit/Generation of Profit & 14.3 & 17.5 \\
Value Creation & 5.7 & 3.1 \\
Other Outcomes & 0 & 11.3 \\
\hline
\end{tabular}

*indicates significant difference at $\alpha=.05$

Table 4: Percentage of each category included by students who have or do not have an entrepreneur as a close relative or mentor

\begin{tabular}{ccc}
\hline Category & $\begin{array}{c}\text { Students with } \\
\text { Relative }\end{array}$ & $\begin{array}{c}\text { Students without } \\
\text { Relative }\end{array}$ \\
\hline
\end{tabular}

Creation/Development of a: 
Business

Product

Service

Venture

Entrepreneurial Skills

Creativity and Innovation

Opportunity Recognition

Idea Generation and Development

Bringing an Idea to Market

Drive/Motivation/Taking Action

Taking a Risk/Investing

Resource Management

Other Skills/Abilities

Goals and Outcomes

Financial and Intellectual Independence

Pursuit/Generation of Profit

Value Creation

Other Outcomes
39.2

10.3

5.2

13.4

28.9

8.2

19.6

24.7

30.9

18.6

3.1

41.2

26.8

17.5

2.1

9.3
44.4

11.1

5.6

16.7

13.9

8.3

33.3

30.6

16.7

22.2

0.0

27.8

27.8

13.9

8.3

5.6

Table 5: Percentage of each category included by students who enrolled in different colleges

\begin{tabular}{lccccc}
\hline Categories and Themes & Engineering & Business & Comm. & $\begin{array}{c}\text { Hotel } \\
\text { Mgnt. }\end{array}$ & Other \\
\hline Creation/Development of a: & & & & & \\
Business & 43.2 & 27.8 & 53.3 & 44.8 & 66.7 \\
Product & 10.8 & 11.1 & 20.0 & 3.4 & 13.3 \\
Service & 5.4 & 5.6 & 13.3 & 0.0 & 6.7 \\
Venture & 10.8 & 27.8 & 6.7 & 6.9 & 13.3 \\
Entrepreneurial Skills & & & & & \\
Creativity and Innovation & 16.2 & 44.4 & 26.7 & 10.3 & 20.0 \\
Opportunity Recognition & 10.8 & 8.3 & 6.7 & 0.0 & 20.0 \\
Idea Generation and Dev. & 27.0 & 19.4 & 13.3 & 31.0 & 13.3 \\
Bringing an Idea to Market & 24.3 & 13.9 & 33.3 & 34.5 & 40.0 \\
Drive/Motiv./Taking Act. & 21.6 & 38.9 & 33.3 & 10.3 & 40.0 \\
Taking a Risk/Investing & 21.6 & 27.8 & 20.0 & 17.2 & 0.0 \\
Resource Management & 2.7 & 5.6 & 0.0 & 0.0 & 0.0 \\
Other Skills/Abilities & 56.8 & 38.9 & 20.0 & 27.6 & 20.0 \\
Goals and Outcomes & & & & & \\
Financial and Intell. Indep. & 21.6 & 30.6 & 33.3 & 27.6 & 26.7 \\
Pursuit/Gen. of Profit & 21.6 & 2.8 & 20.0 & 27.6 & 13.3 \\
Value Creation & 2.7 & 5.6 & 0.0 & 6.9 & 0.0 \\
Other Outcomes & 13.5 & 2.8 & 0.0 & 13.8 & 0.0 \\
\hline
\end{tabular}

Table 6: Frequency of male and female students enrolled in different colleges 


\begin{tabular}{cccccc}
\hline Gender & Engineering & Business & Comm. & $\begin{array}{c}\text { Hotel } \\
\text { Mgnt. }\end{array}$ & Other \\
\hline Males & 33 & 25 & 10 & 18 & 8 \\
Female & 3 & 11 & 5 & 11 & 7 \\
\hline
\end{tabular}

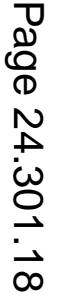

